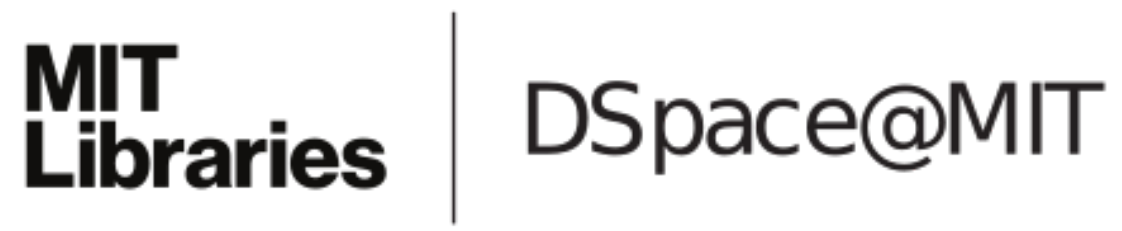

\author{
MIT Open Access Articles
}

Sensitivity and Scenario Results

The MIT Faculty has made this article openly available. Please share how this access benefits you. Your story matters.

Citation: Yu, Winston, Yi-Chen Yang, Andre Savitsky, Donald Alford, Casey Brown, James Wescoat, Dario Debowicz, and Sherman Robinson. "Sensitivity and Scenario Results." The Impacts of Climate Risks on Water and Agriculture (April 18, 2013): 119-143. ( I International Bank for Reconstruction and Development/The World Bank

As Published: http://dx.doi.org/10.1596/9780821398746_CH06

Publisher: The World Bank

Persistent URL: http://hdl.handle.net/1721.1/90257

Version: Final published version: final published article, as it appeared in a journal, conference proceedings, or other formally published context

Terms of use: Creative Commons Attribution 


\section{Sensitivity and Scenario Results}

\section{Key Messages}

- The integrated model is most sensitive to inflows into the system, crop water requirements, and the depth to groundwater.

- The water allocations per the 1991 Provincial Accord and within provinces are the most critical constraint in the Indus system. By relaxing the Accord constraint and allowing optimal economic allocation between and within provinces, both Punjab and Sindh provinces stand to gain. The ability to manage extreme events (for example, drought) by more reliably meeting system-wide demands is also enhanced.

- Climate futures were examined representing a plausible range of climate changes within the next 80 years consistent with recent observations and theory.

- Gross domestic product (GDP), Ag-GDP, and household income are estimated to decrease by $1.1,5.1$, and 2.0 percent, respectively, on an annual basis as a result of plausible climate changes. In the most extreme future-when inflow is 90 percent exceedance probability and the temperature increases $+4.5^{\circ} \mathrm{C}$-GDP, Ag-GDP, and household income are estimated to decrease by $2.7,12.0$, and 5.5 percent, respectively, on an annual basis.

- Climate impacts on crop production are greatest in Sindh $(-10$ percent on average).

- Irrigated rice, sugarcane, cotton, and wheat demonstrated the greatest sensitivity to climate, and changes represent both response to climate and dynamic responses to water availability and price changes. Milk revenues are also expected to decrease.

- Three possible adaptation investments were evaluated: improvements to system-wide efficiency, construction of new storage, and investments in agriculture technologies to increase crop yield.

- From a system perspective, additional storage provides agricultural benefits by mitigating the effects of droughts, but it provides little additional agricultural benefit (assuming no expansion of the current irrigated area) in other years. 
This is at least partially due to the current constraints on agricultural production, including allocation constraints such as the 1991 Accord.

- Although the model does not optimize for hydroelectricity production, additional storage does result in increased hydropower and consequent economic benefit. Flood risk reduction was not considered in this report but is potentially significant.

- Canal efficiency and crop yield investments show potential to minimize the impacts of future climate risks and meet food self-sufficiency objectives, increasing production by $5-11$ percent on average and offsetting future climate losses.

- Without specific interventions, environmental considerations, such as flow to the sea, changes in depth to groundwater, and the overall salinity situation, are projected to worsen. Potential adjustments to climate and food risks need additional investigation.

\section{Sensitivities of Hydrologic Parameters and the DIVACRD Constraint}

The most sensitive parameters in the Indus Basin Model Revised (IBMR) (figure 6.1a) are stream inflow into the Indus, crop water requirement, and depth to groundwater. The objective value can change significantly with different available inflows. The lowest total inflow tested (90 percent exceedance probability) is 101 million acre-feet (MAF) and the highest value (10 percent exceedance probability) is 209 MAF. The objective value decreases to almost 60 percent of the baseline (see chapter 5, section "Baseline: Year 2008-09") when the inflows drop to 101 MAF. When the inflow increases to 209 MAF, the objective value change is small $(+0.1$ percent from the baseline). That is, for high-flow settings, the system is unable to generate more economic benefits in the basin given the current constraints, including water allocation requirements from the 1991 Accord and physical capacity and land area constraints (that is, irrigated area served by the Indus Basin Irrigation System [IBIS] is fixed).

Increasing temperatures are expected to increase evaporative demand from crops and soils, which would increase the amount of water required to achieve a given level of plant production (Brown and Hansen 2008). The crop water requirement parameters in IBMR are based on theoretical consumptive requirements, survey data, and model experiments of water balances of the entire basin (Ahmad, Brooke, and Kutcher 1990). A local study by Naheed and Rasul (2010) is used to link crop water requirement and air temperature change under the assumption that crop phenology and management will remain the same under different air temperature conditions. The modeling results indicate that when the crop water requirement increases more than 5 percent above the baseline irrigation requirements (corresponding to a temperature increase larger than $2^{\circ} \mathrm{C}$ ), the objective value drops significantly. Figure 6.1 a shows that this temperature increase will result in a 42 percent decrease in the objective value (from the baseline). The highest tested crop water requirement is +35 percent more than the baseline which corresponds to a $6.5^{\circ} \mathrm{C}$ temperature increase. 
Figure 6.1 IBMR Sensitivity Analysis Results

a. Sensitivity analysis results on hydrologic parameters

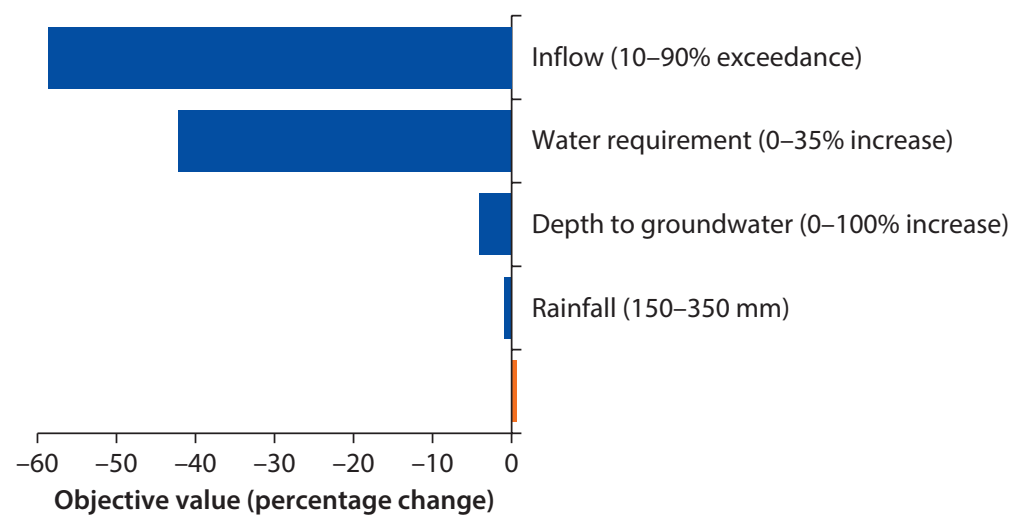

Note: IBMR = Indus Basin Model Revised. Objective value baseline = PRs 2,850 billion.

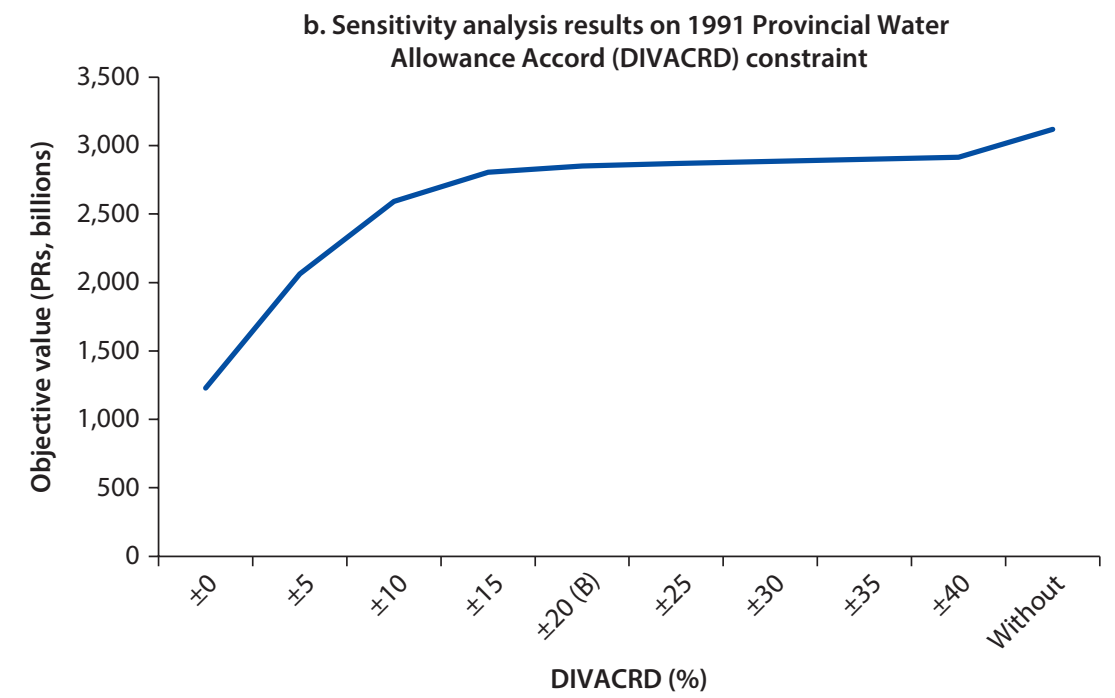

Note: Empty data points indicate the use of imaginary water. The " \pm "means tolerance range, the "(B)" means baseline and "Without" means runs without the Accord.

This is an unlikely temperature change in the next several decades but illustrative of the dynamics and sensitivity of the system.

The objective value is also sensitive to the depth to groundwater, which varies across agro-climatic zones (ACZs). Figure 6.1a shows that the objective value decreases by about 4 percent when average groundwater depth doubles throughout the system. Note that the unit pumping cost is constant (a function of volume only) and does not increase with depth. This is a limitation in the current model. Groundwater issues are discussed further in the "Environment Issues" section.

The historical canal diversion constraint (DIVACRD) simulates the 1991 Provincial Accord requirement (described in chapter 2). This water allocation 
Table 6.1 Analysis of Impact across Provinces with and without the Provincial Accord (PRs, millions)

\begin{tabular}{|c|c|c|c|c|c|c|c|}
\hline Province & $\begin{array}{c}\text { Revenue } \\
\text { (PRs, millions) }\end{array}$ & $\begin{array}{c}\text { Cost } \\
\text { (PRs, millions) }\end{array}$ & $\begin{array}{c}\text { Net } \\
\text { revenue }^{\mathrm{a}}\end{array}$ & $\begin{array}{l}\text { Profit change if } \\
\text { remove DIVACRD }\end{array}$ & $\begin{array}{c}\text { Canal diversion } \\
(M A F)\end{array}$ & $\begin{array}{c}\text { Change in } \\
\text { canal diversion }\end{array}$ & $\begin{array}{r}\text { Marginal } \\
(P R s / A F) \\
\end{array}$ \\
\hline \multicolumn{8}{|c|}{ Fixed provincial allocation } \\
\hline Punjab & $2,390,054$ & 433,072 & $1,956,982$ & & 55.8 & n.a & n.a \\
\hline Sindh & 573,822 & 116,339 & 457,482 & & 45.6 & n.a & n.a \\
\hline Others & 104,218 & 27,257 & 76,961 & & 9.3 & n.a & n.a \\
\hline \multicolumn{8}{|c|}{ Optimized allocation } \\
\hline Punjab & $2,503,663$ & 463,216 & $2,040,447$ & $83,464(4 \%)$ & 61.4 & 5.6 & 14,904 \\
\hline Sindh & 718,849 & 178,782 & 540,067 & $82,584(18 \%)$ & 57.0 & 11.4 & 7,244 \\
\hline Others & 103,913 & 34,038 & 69,876 & $-7,086(-9 \%)$ & 6.6 & -2.7 & $-2,624$ \\
\hline
\end{tabular}

Note: n.a. = not applicable, DIVACRD = 1991 Provincial Water Allocation Accord, MAF = million acre-feet, AF = acre-foot.

a. Net revenue $=$ revenue-cost.

constraint is the most critical constraint in the model. Figure 6.1b shows the objective value for varying levels of the constraint-from strict adherence to no constraint. For a $\pm x$ percent deviation, canal diversions can vary between a $(1-x)$ to $(1+x)$ fraction of the historical canal allocations. As the constraint is increasingly relaxed, more objective value (that is, economic benefit) is possible. The objective value ranges by a factor of 2 . When the deviation allowed is smaller than \pm 15 percent, the objective value shows the largest changes. By fully relaxing this constraint, the largest objective value is achieved. Under these circumstances, the only binding constraint becomes the actual physical capacity of the system, both canal and land capacities. Note that for subsequent scenarios, a \pm 20 percent deviation is used as the baseline. This is the point at which sufficient irrigation water is available.

Table 6.1 shows the impact of DIVACRD across the different provinces. By completely relaxing this constraint, the optimized allocation results in additional canal water to both Punjab and Sindh and a consequent increase in economic benefits to both. In absolute terms, the additional net revenues in Punjab are estimated to be PRs 83,464 million (US\$1.04 billion); for Sindh they are estimated to be PRs 82,584 million (US\$1.03 billion in 2009). The increase in Sindh (18 percent) is larger in percentage terms than Punjab (4 percent). Moreover, a marginal analysis was done on this constraint over the entire basin which revealed that the incremental value-added per acre-foot (AF) is greatest in Punjab. This reflects the higher net returns from the agriculture sector in Punjab.

The aggregate gains from relaxing DIVACRD involve relative gains by some ACZs, canal commands, and crops as compared with others. This results from the allocation of water to its most economically productive uses at the ACZ level. Thus, the model simulates optimal economic allocation both between and within provinces. For example, while Punjab would gain a 5 percent increase in canal diversions with the relaxation of DIVACRD, the model also shows that within Punjab some ACZs would lose up to 5 percent. Thus, in order to implement and realize the full benefits of relaxing the 1991 Accord, consideration of how to provide incentives for winners and losers within provinces may be as important 
(or more) than the needed incentives between provinces, which for Sindh and Punjab are self-evident at the provincial level.

The potential benefits of relaxing the DIVACRD constraint look promising. However, these optimization results must be weighed in relation to the current state of interprovincial water relations and administration. As noted in chapter 2 , the 1991 Accord was established to clarify interprovincial shares, that is, with the aim of increasing the reliability of provincial shares and deliveries, and thereby increasing the prospect for consensus on future infrastructure development of the sort envisioned by the Water Sector Investment Planning Study (WSIPS, WAPDA 1990). Unfortunately, neither aim has been sufficiently achieved. Briefly, Sindh did not trust Punjab's diversions before independence in 1947, let alone before the Accord of 1991 (see Michel 1967); neither province has trusted the other or Indus River System Authority (IRSA) under the Accord as currently administered; and presumably they would not expect to the other to take or receive their "optimal shares" under a relaxed Accord. IRSA's technical and administrative limitations have been discussed in previous studies (see review by Tariq and U1 Mulk 2005, for Briscoe and Qamar 2006).

Furthermore, it is worthwhile noting that the measurement of actual canal flows, watercourse diversions, and water uses remains uncertain and disputed. Provincial departments have sought in various ways to raise the empirical standards for monitoring irrigation water diversions and use. At the interprovincial level, however, Pakistan made an unsuccessful effort to install telemetry equipment to improve real-time data quality for deliveries under the 1991 Accord, which IRSA eventually had to abandon. There have been recent calls for renewed investment in an advanced, high-quality measurement system.

Finally, even though it is unlikely and probably unwise that the DIVACRD constraint should-by itself-be relaxed, there is room for flexible policy adjustments and mechanisms within the wider framework of the present Accord (for example, interprovincial exchange of surplus allocations, water banking, and leasing arrangements), which the IBMR modeling results suggest should be pursued on agro-economic grounds. These could include mechanisms within provinces for exchanging water for compensation and also mechanisms for exchange between provinces. The results suggest that there may be significant gains not only in terms of relaxing the provincial Accord but also in implementing economic allocation within provinces. In fact, neither is mutually exclusive, and the greatest gains would result from economic allocation at both levels.

\section{Future Climate Risk Scenarios}

Climate scenarios were developed to examine the effects of possible hydrological or climatic changes that may occur in the future. Given the low confidence in general circulation model (GCM) projections in this region (Immerzeel et al. 2011), a more robust approach would be to evaluate responses across a wide range of plausible climate futures. Note that some of the future scenarios include greater precipitation, but all feature warmer temperatures. A future year is not 
specified since the IBMR is a single-year model. All results are compared with a baseline based on current climate. Thus, results for investments are presented as percent changes to those same investments under the current climate. The baseline includes the DIVACRD constraint. Results are presented as boxwhisker plots and show 1st, 25th, 50th, 75th, and 99th percentiles. It must be noted that, since these are single-year runs, impacts are likely to be underestimated since the model assumes reservoirs are at full storage at the beginning of the year. Moreover, the depth to the water table is the same across scenario runs. For these reasons a limited multiyear version of the model was created to allow these resources to dynamically vary to illustrate the benefits of the investment scenarios examined (discussed later in the section, "Long-Term Characteristics of Investments and Water Productivity").

\section{Climate Risk Scenarios}

To generate a wide range of potential climate scenarios, combinations of corresponding inflow and crop water requirement parameters are used. Inflow is varied from 10 to 90 percent exceedance probability using 10 percent increments, and the crop water requirement is varied from +2.5 , +5 , to +20 percent, corresponding to $1^{\circ}-4.5^{\circ} \mathrm{C}$ temperature increases (possibly occurring around the 2020s and 2080s, respectively (based on the GCM outputs from chapter 4). Furthermore, since much of the waters in the system originate from the Upper Indus Basin (UIB) in the Himalaya, climate change impacts (using corresponding temperature and precipitation changes) on snow and ice in the UIB, and ultimately on the inflows into the Indus main-stem basin (as described in table 4.10) are included. From these, a total of 70 different climate futures are generated. These scenarios represent a plausible range of climate change futures within the next 80 years consistent with recent observations and theory. The impacts of these climate futures on the computable general equilibrium (CGE) and IBMR outputs are shown in figure 6.2.

Generally, negative impacts are estimated under these climate risk scenarios. Gross domestic product (GDP), Ag-GDP, and household income are estimated to decrease by $1.1,5.1$, and 2 percent, respectively. In the most extreme climate future (when inflow is 90 percent exceedance probability and the temperature increases $+4.5^{\circ} \mathrm{C}$ ), GDP, Ag-GDP, and household income are estimated to decrease by $2.7,12$, and 5.3 percent, respectively. Figure 6.3 also demonstrates that most of the negative impacts on incomes will occur for those households outside of the agriculture sector (except for those living in provinces other than Punjab and Sindh). Since the increase in prices is larger than the decrease in production, farm-related households will likely benefit. However, non-farm households (for example, urban) will have to pay more for food, thus resulting in decreasing household incomes. When the aggregated household income is calculated at the national level, the model weighted each household against their baseline incomes. Since non-farm households have higher weights, the aggregated household income shows a negative impact. 
Figure 6.2 CGE and IBMR Outcomes under Climate Risk Scenarios

a. Impacts on GDP, Ag-GDP, and household income

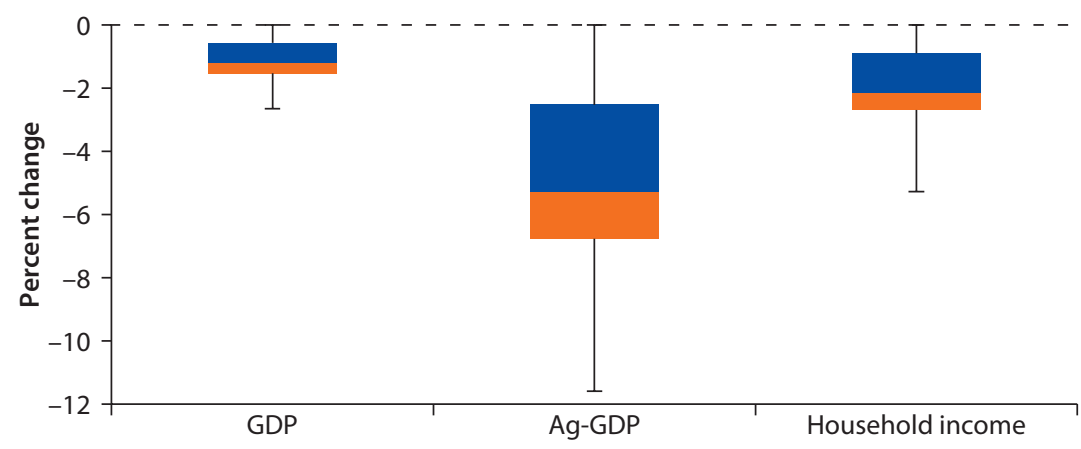

b. Impacts on crops and power

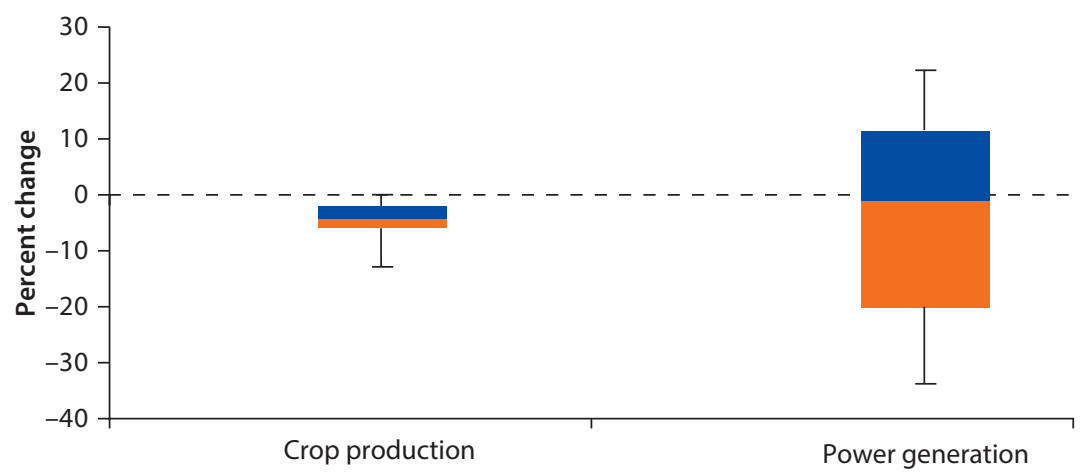

Note: $\mathrm{CGE}=$ computable general equilibrium, IBMR = Indus Basin Model Revised. The upper error bar represents 99 percent, the upper box represents 75 percent, the middle line of the box represents 50 percent, the lower box represents 25 percent and the lower error represents 1 percent.

Figure 6.3 Household Income Changes under Various Climate Scenarios for Different Households

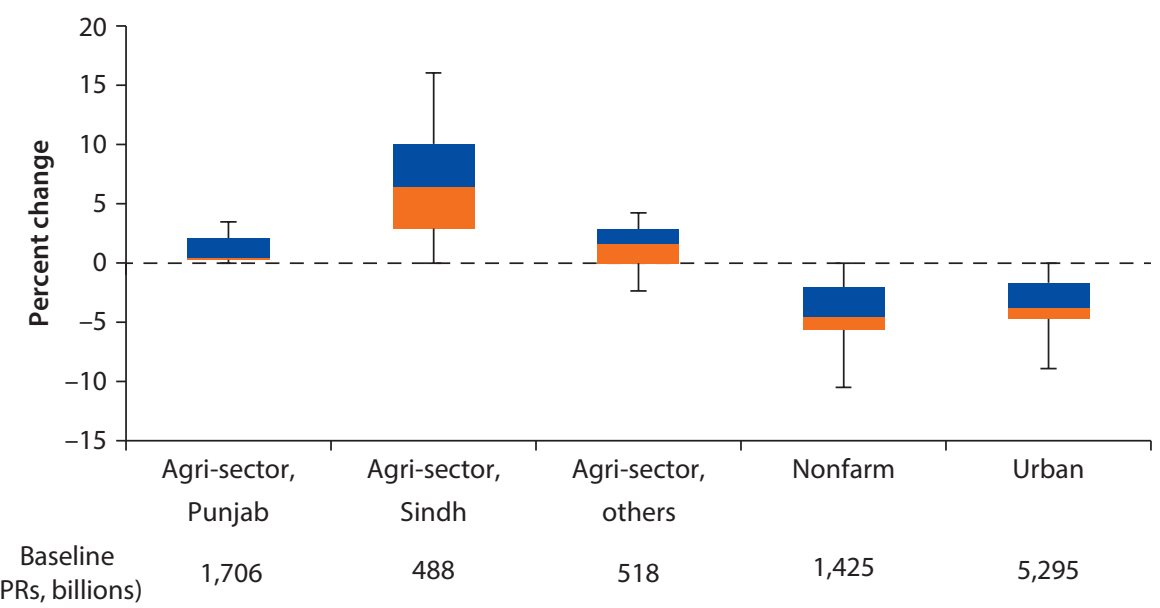


Figure $6.2 \mathrm{~b}$ shows that total crop production is estimated to decrease $0-13$ percent. The change in power generation varies the most, from +22 percent to -34 percent. Increases are due to more surface water becoming available from more snow-melt.

Figure 6.4 breaks down the crop production into different provinces and crops. The production changes are greatest in Sindh (around 10 percent on average). In the most extreme climate future, a 36 percent decrease in crop production is estimated in Sindh and a 5 percent decrease in Punjab. Figure $6.4 \mathrm{~b}$ shows five crops that contribute most to the total crop revenue (see table 5.2). The largest projected production decrease will be for irrigated rice and sugarcane where, in the worst case scenario, almost 25 percent and 20 percent decreases, respectively, are estimated (6 percent and 5.7 percent average decrease). The worst-case scenarios for cotton and wheat are reductions of 2 percent and 7 percent, respectively. Basmati rice has a very small negative impact (less than 1 percent) under these climate futures. Note that these impacts do not consider changes in the biological crop yield response (beyond those changes due to water requirements) in these simulations. According to Iqbal et al. (2009), for instance, using a bio-physiological based model, wheat yields are expected to decrease about 3 percent under the A2 scenario and 5 percent under B2 in the 2080s. Thus, these changes would be in addition to what this study's model currently predicts.

Figure 6.4 Crop Production Changes under Climate Risk Scenarios

a. Results by province

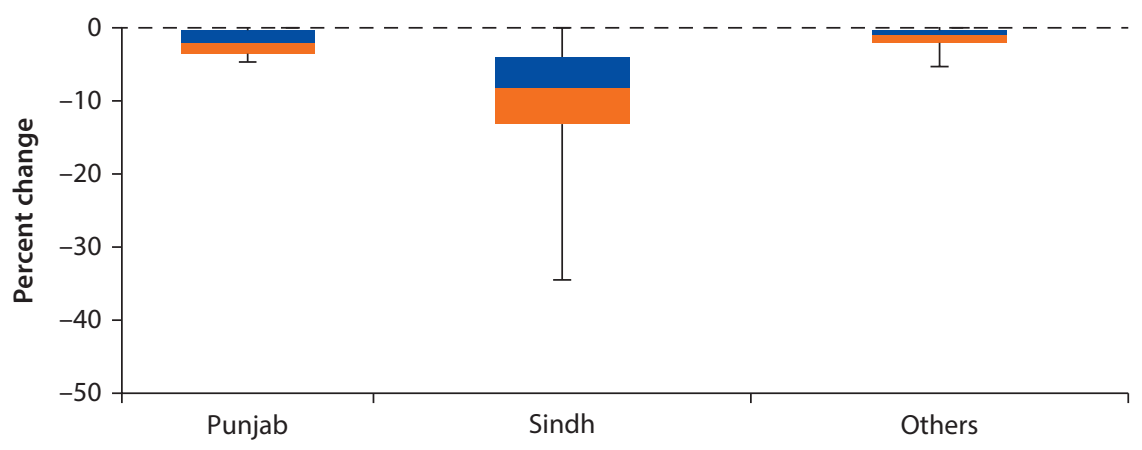

b. Results by major crop

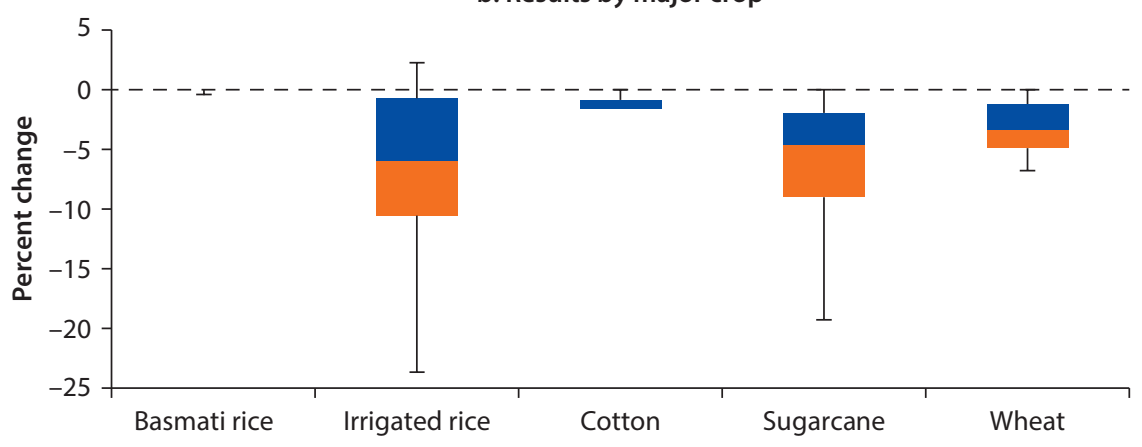


Figure 6.5 Commodities Revenue under Climate Risk Scenarios

a. Results by crop

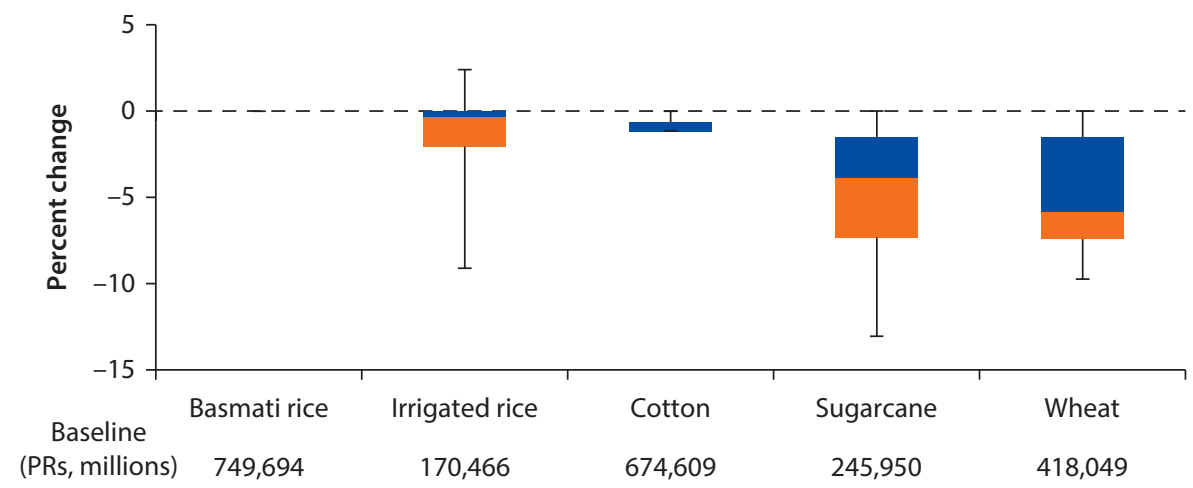

b. Results by livestock product

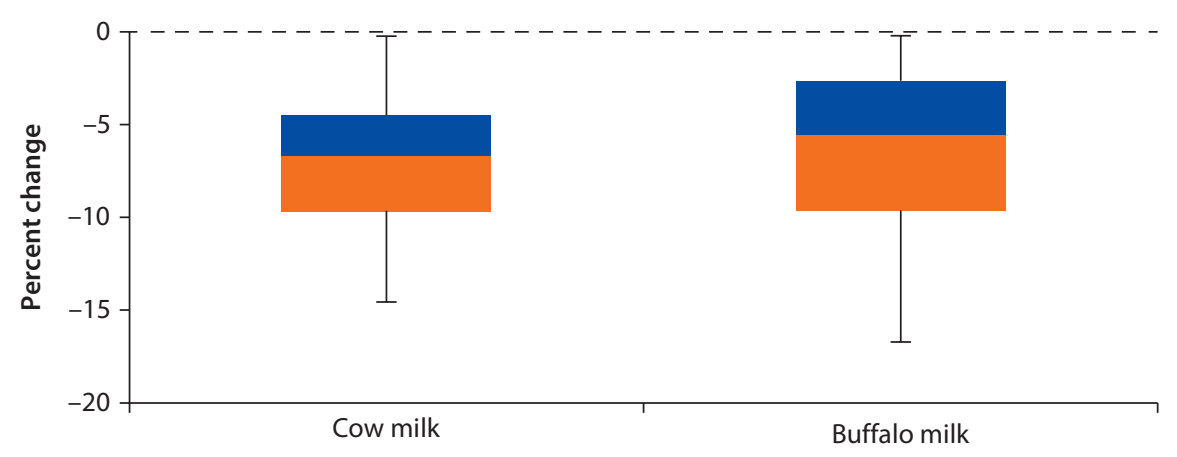

Figure 6.5 shows that the largest changes in revenue are estimated for wheat, sugarcane, irrigated rice, and cow and buffalo milk. In the extreme climate futures, sugarcane and irrigated rice revenues may drop by as much as 13 percent. Irrigated rice under the best circumstances may marginally increase in revenue.

\section{Hydrograph Monthly Shift Scenario}

The climate risk scenarios present the inflow, precipitation, and temperature change impacts under the assumption that the intra-annual hydrological pattern will remain the same. This section presents an evaluation of the effect of a shift of the hydrograph one month forward (April inflow becomes March inflow) and backward (April inflow becomes May inflow). A monthly shift forward is consistent with what a warming climate might do as described earlier (see chapter 4) that is, earlier snow melt and peak flow. Figure 6.6a shows that a forward monthly shift can have a larger negative impact on the economy than a backward shift. This impact is larger in magnitude than the average climate risk scenario. Figure $6.6 \mathrm{~b}$ shows also the crop production and hydropower generation impacts. Less power is generated with these hydrograph shifts since less water is stored. 
Figure 6.6 CGE and IBMR Outcomes under Hydrograph Monthly Shift Scenarios

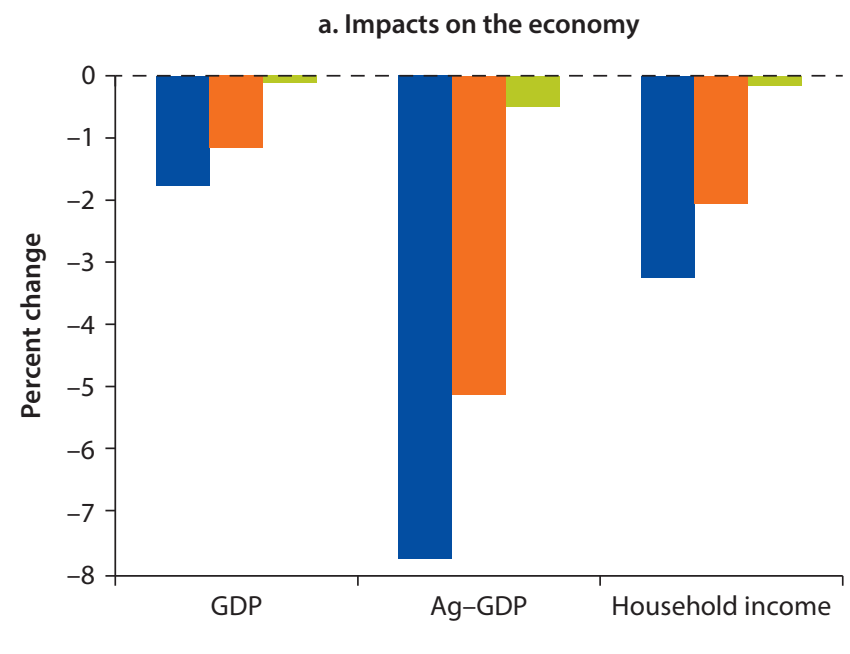

b. Impacts on crop and power production

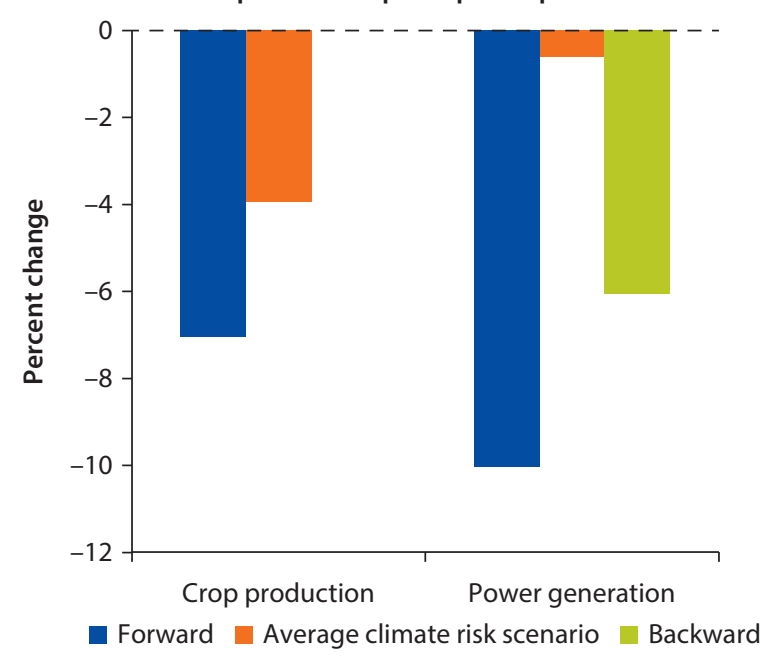

\section{"Worst" and "Best" Case Climate Scenarios}

The possible "worst" and "best" case climate futures represent low probability but possibly high impact scenarios ("surprise events"). The worst case is defined as the 90 percent exceedance probability inflow (only 10 percent of flows are less than this level), a forward monthly hydrograph shift, 20 percent less rainfall, 20 percent more water requirement (consistent with a $+4.5^{\circ} \mathrm{C}$ change), and groundwater table depths 20 percent deeper throughout the basin. The best case is defined as the 10 percent exceedance probability inflow (90 percent of flows are less than this level), 20 percent more rainfall, no change in the existing crop water requirements, and groundwater table depths 20 percent shallower. Almost all GCM projections indicate increasing temperatures in the future and a high uncertainty in the direction and magnitude of precipitation change. However, 
given the counteracting nature that temperature and precipitation can play in overall water availability in the Indus system, the probability of the best and worst climate scenarios is believed to be quite small. That is not to say, however, that extreme events may increase in frequency in the future, a prediction whose science is yet inconclusive.

In the worst case, GDP, Ag-GDP, and household income decrease by 3.1, 13.3, and 6.1 percent, respectively, on an annual basis (figure 6.7a). In the best case, GDP, Ag-GDP, and household income increase by 1.0, 4.2, and 1.3 percent,

\section{Figure 6.7 CGE and IBMR Outcomes under the "Worst" and "Best" Case Scenarios}

a. Impacts on the economy
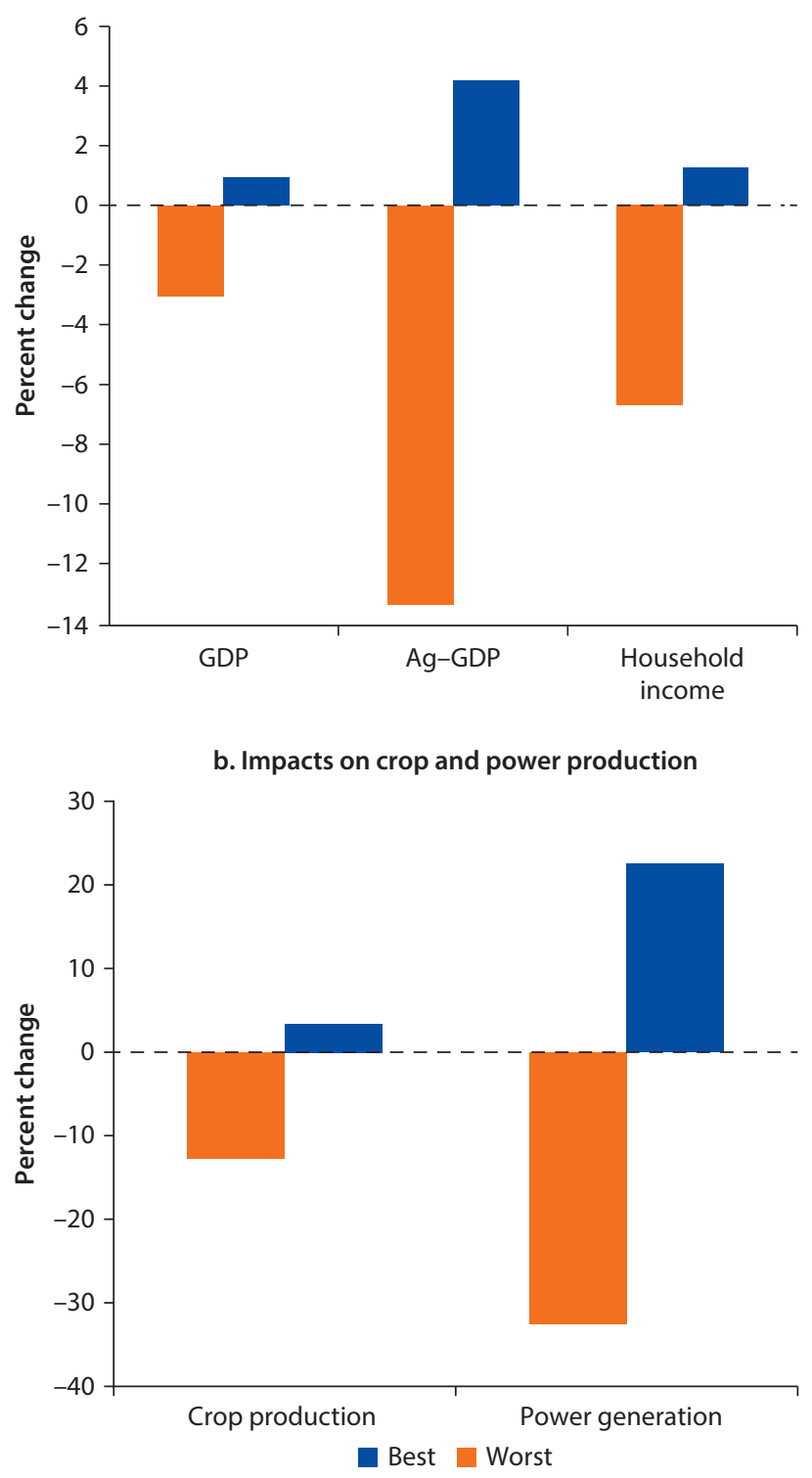
respectively. These ranges represent a range of possible economic futures in the basin. Figure $6.7 \mathrm{~b}$ shows that the crop production decreases by 13 percent and increases by 3 percent under the worst and best scenarios, respectively. Similarly, power generation decreases by 32 percent and increases by 23 percent under worst and best scenarios, respectively. These results indicate that power generation is more sensitive to climate changes than crop production. This in part reflects the alternative source of irrigation (that is, groundwater) available for crop production and alternative cropping patterns.

\section{Adaptation Investment Scenario Analyses}

Three different investments are discussed in this section: canal and watercourse efficiency improvements (CANEFF), new reservoir construction, and crop yield improvement investments. To examine the role played by each of these investments over time the original IBMR is modified for a limited multiyear analysis (Indus Basin Multi-Year: IBMY). The IBMY uses the entire 50 year historical inflow time series (1961-2010). In the IBMY, the December reservoir storage from the previous year becomes the initial storage for the current year. Moreover, depth to water table is revised each year. All other data, including the crop water requirements, precipitation, price, and demand data, are assumed to be the same each year. Thus, only the water resource endowment is dynamic.

\section{Improving System-Wide Efficiency}

The first adaptation investment is to improve system-wide efficiency (CANEFF). The current canal and watercourse efficiency is estimated to be only 76 and 55 percent, respectively. Thus, only about 40-50 percent of the water in the system is actually available for field level irrigation. Several previous studies have addressed this issue (PRC Engineering 1986; World Bank 1996). For example, Cooley, Christian-Smith, and Gleick (2008) evaluated four different water-saving scenarios for the irrigation systems in California. Two commonly used technologies are sprinkler and drip/micro-irrigation systems. Sprinkler irrigation delivers water to the field through a pressurized pipe system and distributes it via rotating sprinkler heads, spray nozzles, or a single gun-type sprinkler. The field efficiency for sprinkler irrigation system is about 70-75 percent (Cooley, Christian-Smith, and Gleick 2008). Drip irrigation is the slow application of low-pressure water from plastic tubing placed near the plant's root zone. Drip systems commonly consist of buried PVC pipe mains and submains attached to surface polyethylene lateral lines. The field efficiency for sprinkler irrigation system is about 87.5-90 percent (Cooley, Christian-Smith, and Gleick 2008). Canal lining is another traditional approach to improving irrigation system efficiency. It can control seepage to save water for further extension of the irrigation network and also reduce waterlogging in adjacent areas (Swamee, Mishra, and Chahar 2000). Skogerboe et al. (1999) estimated that for the Fordwah Eastern Sadiqia project in Punjab, different types of canal lining can reduce the seepage losses by 50 percent. This study models an adaptation investment scenario whereby 
the system-wide efficiency is improved to 50 percent (from the existing 35 percent)_-primarily through canal and watercourse improvements.

\section{New Storage in the Indus Basin}

The second adaptation investment is the construction of new reservoirs (NEWDAM). The construction of large dams can increase the country's water storage capacity and better manage scarcity. New dams will also add power generation; thereby helping to meet the country's expanding electricity needs. In this analysis, additional storage is primarily evaluated in terms of its ability to improve agricultural production for the existing irrigation system under climate change conditions. The potential economic value of storage for flood risk reduction, improved drought management, and expansion of the irrigated area is not included. Although hydropower production is estimated, the value of that electricity is not included here, and thus does not factor into GDP or objective function results. Thus, this evaluation should not be seen as a cost-benefit analysis of new dam construction. The adaptation investment used here introduces about 13 MAF into the modeling structure. The operation rules and storage-level relationship is assumed the same as the existing reservoirs in the system.

\section{Improving Crop Technologies and Yields}

The third adaptation investment is new crop technologies to improve crop yields (CYIELD). As noted earlier, it is assumed that crop yield is constant over time for each crop at each ACZ. However, it is reasonable to assume that crop yields will improve in the future as a result of new technologies and on-farm water management improvements (as shown in figure 2.10). For example, biotechnology investments in genetically modified (GM) crops promise great benefits for both producers and consumers of agricultural products, although the applications of GM are also associated with potential risks (FAO 2002).

One of the most successful examples of biotechnology is the application of BT cotton in China. Based on survey data, Huang et al. (2002) reported that farmers who used BT cotton observed increased output per hectare and increased their incomes due to reduced pesticides and labor inputs. Since no detailed GM crop data is available, a rough estimation was made of crop yield improvement based on FAO (2002) data on yield trends for different areas and different crops. For example, for developing countries the wheat yield improvement is about 2.0 percent per year and for rice is about 1.1 percent per year (over the 1989-99 period). The model includes an adaptation investment that assumes a 20 percent yield improvement, which will represent the possible yield in the next 10-20 years according to FAO estimates.

\section{Long-Term Characteristics of Investments and Water Productivity}

The cumulative distribution functions (CDF) of the IBMR objective value for the three investment scenarios just described from the 50-year historical record are presented in figure 6.8. The CDF is a graph that describes the probability of finding an objective value at that value or less. This 50 -year simulation includes 
Figure 6.8 Cumulative Distribution Functions of IBMR-2012 Objective Value for Different Adaptation Investments (without Climate Risk Scenarios)

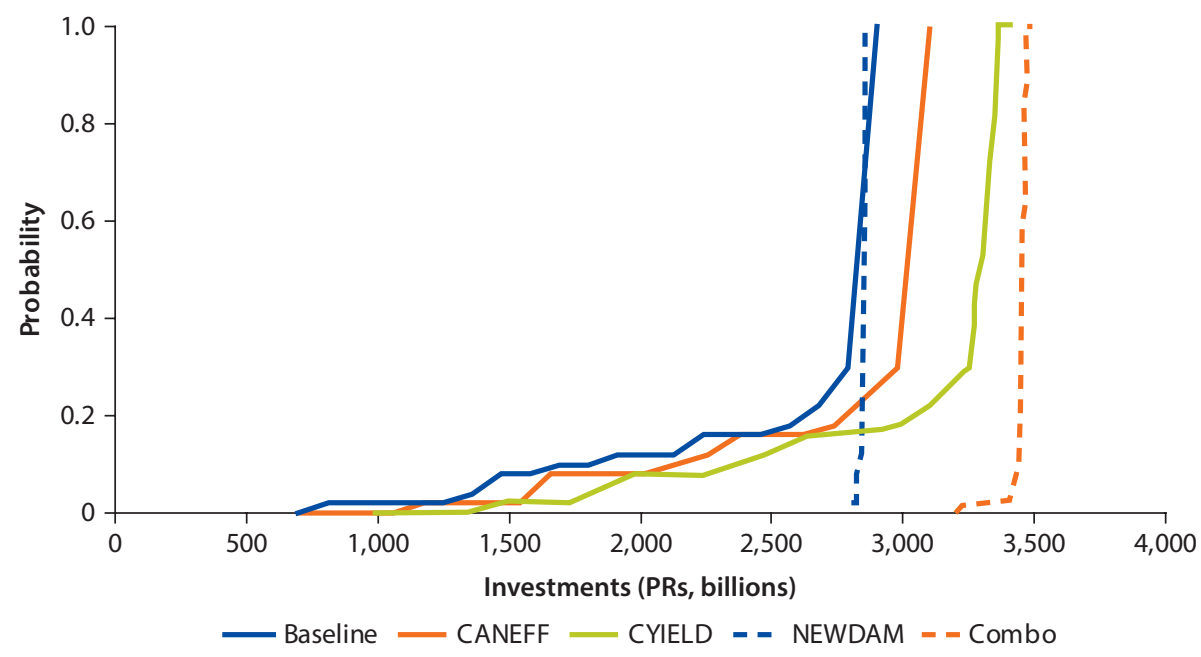

Note: CANEFF = canal and watercourse efficiency improvement, CYIELD = crop yield, NEWDAM = construction of new reservoirs. The cumulative distribution function (CDF) is a graph of the value of the objective function versus the probability that value will occur.

drought years and correspondingly low values of the objective value. The CANEFF and CYIELD investments shift the CDF to the right of the baseline, indicating that the average objective value tends to increase under these investments. The long left-side tails of the CDFs of these two investments are due to very low values that occurred in difficult years, such as the droughts that occur over the 50 year simulation. The NEWDAM investment is unique in that it eliminates the left-side tail, showing that additional storage reduces the probability of very low objective values, thus mitigating the effects of drought years. However, it does not increase the objective value under normal and high flow years. This is primarily because the objective function does not include the economic benefits from additional hydropower generation and flood control. In addition, while the increased reservoir volume may supply more water as a result of the constraints of the Accord, that water cannot be put to use effectively. "Combo" is all three investments combined. Summary statistics for these CDFs are shown in table 6.2. Notice that all mean values are higher than the baseline and that the standard deviation is reduced, especially so for the NEWDAM investment.

\section{Performance of Adaptation Investment}

This section is an evaluation of the performance of the adaptation investments under the range of future climate risk scenarios. The DIVACRD constraint is enforced in all model runs. Figure 6.9 and table 6.3 show that the CANEFF and CYIELD investments can significantly improve macroeconomic performance and household income under a climate change future. Instead of losses of 1, 5, and 2 percent for GDP, Ag-GDP, and household income, respectively, with these 
Table 6.2 Mean and Standard Deviation Objective Value for 50 Years from Different Investments

\begin{tabular}{lrr}
\hline & \multicolumn{2}{c}{ With DIVACRD } \\
\cline { 2 - 3 } Objective value (PRs, billions) & Mean & SD \\
\hline Baseline & 2,619 & 491 \\
CANEFF & 2,802 & 465 \\
NEWDAM & 2,843 & 38 \\
CYIELD & 3,085 & 466 \\
Combo & 3,451 & 34 \\
\hline
\end{tabular}

Note: $\mathrm{CANEFF}=$ canal and watercourse efficiency improvement, $\mathrm{CYIELD}=$ crop yield, NEWDAM = construction of new reservoirs.

Figure 6.9 Economic Outcomes from CGE under Different Investments

a. GDP

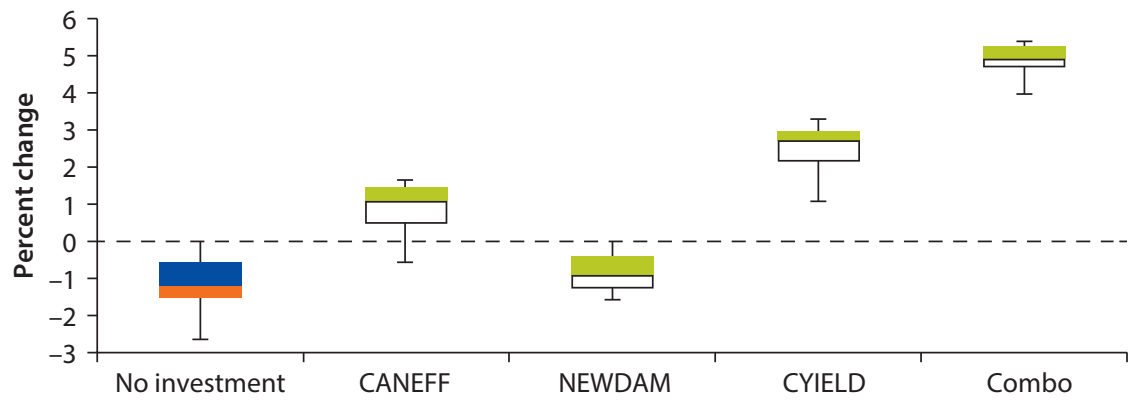

b. Ag-GDP

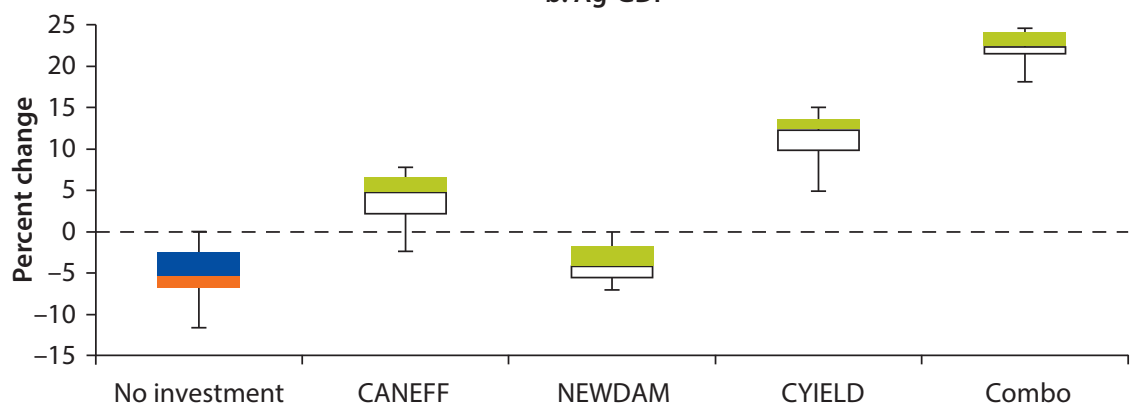

c. Household income

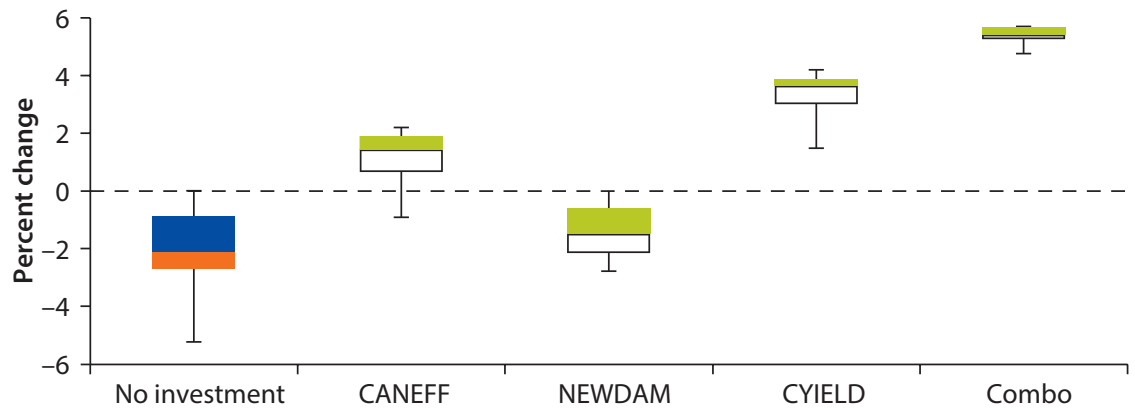

Note: $\mathrm{CGE}=$ computable general equilibrium, $\mathrm{CANEFF}=$ canal and watercourse efficiency improvement, CYIELD = crop yield, NEWDAM = construction of new reservoirs. 
Table 6.3 Impact of Different Adaptation Investments under Climate Risks

\begin{tabular}{lccc}
\hline & GDP & Agri-GDP & Household income \\
\hline $\begin{array}{l}\text { Average change without investments (\%) } \\
\text { No investment }\end{array}$ & -1.1 & -5.1 & -2 \\
Average gain with investments (\%) & & & \\
CANEFF & 2.04 & 9.32 & 3.21 \\
NEWDAM & 0.29 & 1.5 & 0.64 \\
CYIELD & 3.66 & 16.7 & 5.42 \\
Combo & 6.05 & 27.4 & 7.45 \\
\hline
\end{tabular}

Note: CANEFF = canal and watercourse efficiency improvement, CYIELD = crop yield, NEWDAM = construction of new reservoirs.

adaptation investments impacts are positive. For example, the average Ag-GDP will increase by about 4 percent and 11 percent with the CANEFF and CYIELD investments, respectively. The CANEFF and CYIELD investments show a clear positive shift with very low probabilities of observing negative changes. The NEWDAM investment shows minor improvement and reduces the impact of the 1st percentile climate future. As discussed in the previous section, this finding reflects primarily the contribution of additional storage to an existing irrigation system and does not incorporate other potential benefits to the economy and households.

Examining the impact of these investments on crop production and power generation (figure 6.10) shows that the relative efficacy of these investments on crop production is similar. The CANEFF and CYIELD investments result in greater crop production (5-11 percent more on average) than the NEWDAM investment. The NEWDAM investment, on the other hand, can minimize the impacts of extreme climate impact losses and reduce variability. Moreover, the power generation benefits can be quite large with the NEWDAM investment. The highest power generation increase is 130 percent. Even under the worst climate scenario power generation still increases by 20 percent. The economic value of new reservoirs under this analysis would be almost entirely from these power benefits and from a reduction in the impacts of extreme events.

\section{Investment Costs}

The cost of a system-wide canal efficiency program (to achieve the 50 percent scenario) is difficult to quantify because of different approaches used and diversity in geographic conditions. Skogerboe et al. (1999) report that the cost for canal lining in Pakistan (for the Fordwah Eastern Sadiqia Project) ranged PRs 608-3,725 per foot of canal (in 1999 PRs). The reduction in seepage ranged from a factor of $2-10$, depending on the prevalent conditions. Using these indicative costs estimates and assuming that all $60,000 \mathrm{~km}$ of watercourses in the IBIS are lined, a cost range of PRs 180-1,107 billion is calculated. Similarly, system-wide efficiency can be improved directly at the on-farm levels. Cooley, Christian-Smith, and Gleick (2008) estimated the unit cost for sprinkler (US\$1,000-3,500 per acre) and for drip/micro-irrigation systems 
Figure 6.10 IBMR Outcomes under Different Investments

a. Crop production

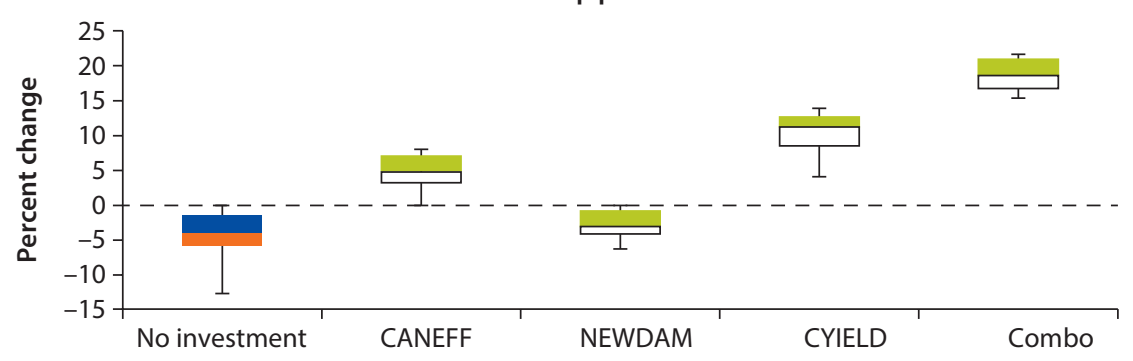

b. Power generation

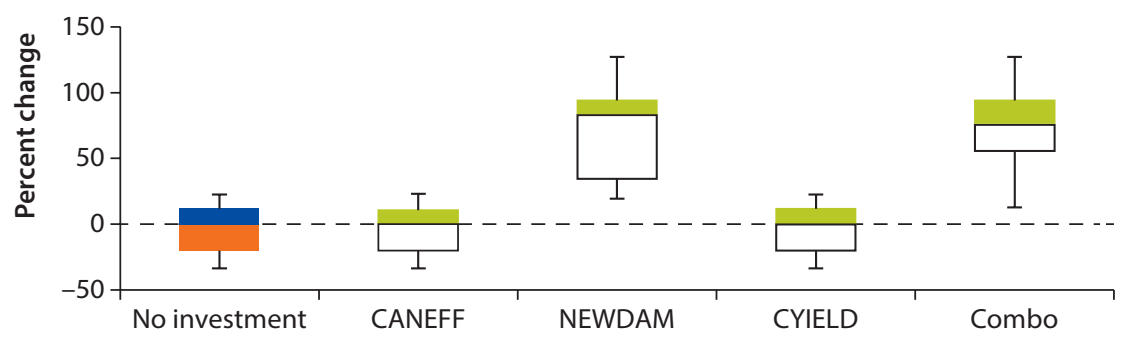

Note: IBMR = Indus Basin Model Revised, CANEFF = canal and watercourse efficiency improvement, NEWDAM = construction of new reservoirs, CYIELD = crop yield.

(US\$500-2,000 per acre). The cost for new storage can be found on the Water and Power Development Authority (WAPDA) website. The estimated cost for Basha and Kalabagh (two often discussed reservoirs) is PRs 390,000 million and PRs 366,000 million in 2005 value, respectively. Therefore, the total estimated cost for new reservoirs construction is PRs 390,000 + 366,000 = PRs 756 billion (US $\$ 9.54$ billion). Finally, estimating the investment cost required for new technologies and research and development to raise crop yields by 20 percent is difficult because of the inherent complexity associated with these investments. According to a study by Menrad, Gabriel, and Gylling (2009), the additional costs per tons for GM and non-genetically-modified rapeseed oil, sugar, and wheat are PRs 32,400, 20,160, and 15,680, respectively, in Germany. Therefore, the average additional cost per tons is PRs 22,746.

\section{Effect of Investments on Food Self-Supply}

Having access to sufficient quantities of food is an indicator of food security. Thus, changes in crop production are directly related to Pakistan's ability to be food self-sufficient, notwithstanding the role that food imports may play. Wheat-based products (flour and bread) are a major part of the diet in Pakistan. These provide upwards of 60 percent of the protein and carbohydrate in the average Pakistani diet (Bastin, Sarwar, and Kazmi 2008). Supply and demand of wheat are used to estimate the impact that climate change may have on the nutritional 
requirements in Pakistan. Bastin, Sarwar, and Kazmi (2008) calculated a conversion factor from wheat production to combined protein and carbohydrate supply in flour. The average value is 70 percent, which means that 1,000 tons of wheat can provide 700 tons of protein and carbohydrate in flour. This converting factor is then multiplied by the 50-year average wheat production and the protein and carbohydrate supply are calculated under baseline and all adaptation investment scenarios. Using the GCM projections from chapter 4, six temperature and precipitation combinations were selected for the 2020s, 2050s, and 2080s (see table 6.4).

The protein and carbohydrate requirement is estimated based on the population. Historical data show a strong linear relationship between Pakistan total population and total requirement of protein and carbohydrate. This equation is used to estimate the protein and carbohydrate requirement in 2020s, 2050s, and 2080s, based on future population estimates. The results of protein and carbohydrate supply and requirement in all these years under all investment scenarios are given in table 6.5. The supply is higher than the demand during the baseline and 2020s time period. However, the supply will be less than demand by the 2050s without any investment. Only the CYIELD investment can maintain the production to meet the future protein and carbohydrate requirements.

Table 6.4 Projected Temperature, Precipitation, and Inflow Changes

\begin{tabular}{ccccc}
\hline Years & $\begin{array}{c}\text { Projected } \\
\text { temperature }\left({ }^{\circ} \mathrm{C}\right)\end{array}$ & $\begin{array}{c}\text { Projected } \\
\text { precipitation (\%) }\end{array}$ & $\begin{array}{c}\text { Crop water requirement } \\
\text { change (\%) }\end{array}$ & $\begin{array}{c}\text { Inflow change (\%) } \\
\text { 2020s }\end{array}$ \\
& +1.5 & Low: 0 & +4 & -4 \\
& & High: +10 & +4 & +4 \\
$2050 \mathrm{~s}$ & +3 & Low: -10 & +10 & -8 \\
& & High: +20 & +10 & +17 \\
$2080 \mathrm{~s}$ & +4.5 & Low: -10 & +20 & +1 \\
& & High: +10 & +20 & +18 \\
\hline
\end{tabular}

Note: Temperature and precipitation projection follow the average general circulation model (GCM) results in chapter 4; inflow changes from current condition are calculated by the model in chapter 3 .

Table 6.5 Protein and Carbohydrate Supply and Requirements under Climate Change Estimates

\begin{tabular}{|c|c|c|c|c|c|c|}
\hline \multirow{2}{*}{\multicolumn{2}{|c|}{$\begin{array}{l}\text { Pakistan population } \\
\text { (millions) }\end{array}$}} & \multirow{2}{*}{$\begin{array}{c}\text { Cereal-based protein and } \\
\text { carbohydrate demand } \\
\text { (tons, millions) }\end{array}$} & \multicolumn{4}{|c|}{$\begin{array}{l}\text { Protein and carbohydrate supply } \\
\text { (tons, millions) }\end{array}$} \\
\hline & & & Baseline & CANEFF & NEWDAM & CYIELD \\
\hline Baseline & 167.4 & 10.1 & 16.3 & 18.0 & 16.4 & 19.8 \\
\hline 2020-low P & \multirow{2}{*}{227.8} & \multirow{2}{*}{13.7} & 16.1 & 17.7 & 16.2 & 19.4 \\
\hline 2020-high P & & & 16.2 & 17.8 & 16.3 & 19.5 \\
\hline 2050-low P & \multirow{2}{*}{307.2} & \multirow{2}{*}{18.4} & 15.8 & 17.2 & 15.9 & 19.0 \\
\hline 2050-high P & & & 15.9 & 17.4 & 15.9 & 19.1 \\
\hline 2080-low P & \multirow{2}{*}{386.7} & \multirow{2}{*}{23.1} & 15.5 & 16.8 & 15.6 & 18.6 \\
\hline 2080-high P & & & 15.5 & 16.8 & 15.6 & 18.7 \\
\hline
\end{tabular}

Note: CANEFF = canal and watercourse efficiency improvement, CYIELD = crop yield, NEWDAM = construction of new reservoirs. Shaded cells mean supply is less than demand. 
By the 2080s, none of the investments can supply sufficient protein and carbohydrates for the country. Disaggregating these findings by province shows that Punjab is able to meet its protein and carbohydrate demands, even out to 2080. The real food security challenge will be in Sindh, even as early as 2020. Note that it is assumed that interprovincial trading does not change and that food imports are not considered.

\section{Environmental Issues}

The primary environmental issues related to water use in the Indus Basin include flow requirements to the sea, groundwater over pumping, and groundwater salinity. These issues were discussed and analyzed in Ahmad and Kutcher (1992). These outcomes are reevaluated here under the climate risk scenarios and investment scenarios described earlier, and the cost for a sustainable groundwater usage situation is also evaluated.

\section{Current Environmental Conditions}

Environmental flows to the sea are required to sustain the diverse deltaic ecosystems and minimize saline intrusion. A minimum $10 \mathrm{MAF}$ to the sea is required per the 1991 Provincial Accord. This minimum flow is difficult to maintain during drought years (for example, 2002-04). Haq and Khan (2010) estimate that over the last 20 years, at least 2 million acres of arable land have been lost in Sindh as a result of salt water intrusion. On average, over the long-term historical record, almost $30 \mathrm{MAF}$ is available to the sea (figure 6.11). This, however, may be an issue in the future if current trends continue. Figure 6.12 shows that the flows below Kotri Barrage (the last barrage in the system) have decreased over time. The annual average from 1936 to 1960 was 87 MAF compared to 41 MAF over the 1977-2000 time period. For future analysis, this modeling

Figure 6.11 Multiyear Flow to the Sea, 1961-2009

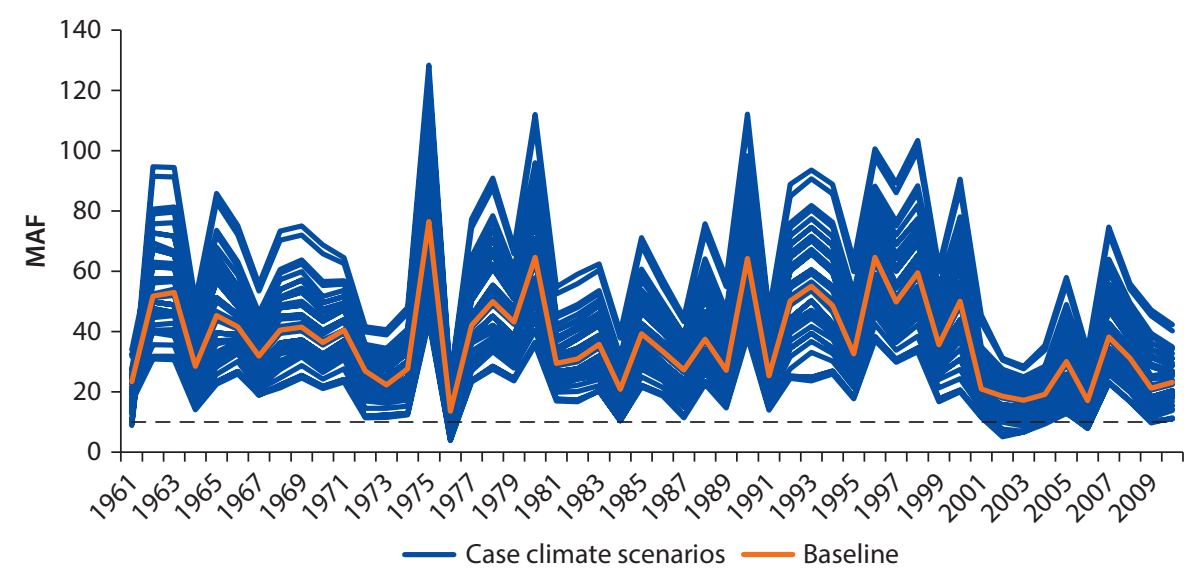

Note: $\mathrm{MAF}=$ million acre-feet. 
Figure 6.12 Historical Flows below Kotri Barrage, 1938-2004

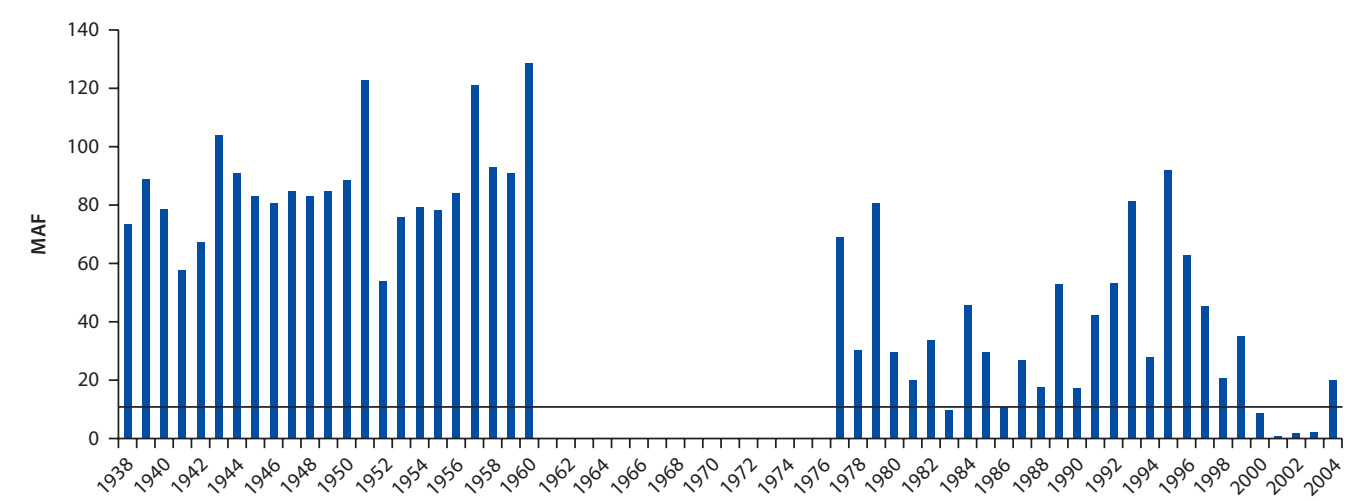

Note: Solid line represents 10 million acre-feet (MAF) established under the 1991 Provincial Water Allocation Accord.

Table 6.6 Baseline Environmental Conditions

\begin{tabular}{lcccccccc}
\hline & \multicolumn{2}{c}{ Area (acres, millions) } & & \multicolumn{2}{c}{ Net recharge $($ MAF) } & & \multicolumn{2}{c}{ Salt balance in soil layer (tons, millions) } \\
\cline { 2 - 3 } Province & Fresh & Saline & & Fresh & Saline & & Fresh & Saline \\
\hline Punjab & 18.1 & 4.8 & & -9.6 & 4.4 & & +35.9 & +4.2 \\
Sindh & 3.4 & 9.4 & & 2.7 & 4.6 & & +5.4 & +29.3 \\
Others & 3.0 & 0.4 & & -2.5 & 0.2 & & +4.5 & +0.7 \\
\hline
\end{tabular}

Note: $\mathrm{MAF}=$ million acre-feet.

framework can be used to test the system-wide implications of various scientifically-based monthly minimum flow requirements.

Groundwater quantity and quality issues are also a prominent environmental issue in the Indus Basin. Punjab faces unsustainable pumping rates while in Sindh the dominant issue is related to problems of salinity and waterlogging. On average, the net recharge in freshwater areas in Punjab (groundwater inflow minus outflow) is $-9.6 \mathrm{MAF}$ and thus the water table is declining (1-6 ft per year). This situation is worst during drought years. On average, the net recharge in the saline areas in Sindh is +4.6 MAF (more groundwater is flowing in than out); as a result the net salt accumulation on the surface in these areas is more than 29 million tons (per year). The reason for this net accumulation is that groundwater pumping does not exist in these saline areas, so fresh water is not recharged into these aquifers. Meanwhile, the evaporation rates in saline areas are usually higher than in fresh areas (due to the higher water table), generating substantial quantities of salt near the ground surface (root zone). The net accumulation of salt in the fresh water areas in Punjab is also quite large because of the large volumes of water being applied for irrigation (which have some background salinity). The baseline groundwater conditions are given in table 6.6.

\section{Sustainable Groundwater Usage}

To evaluate the sustainability of current groundwater usage, assuming an energy cost of PRs 5 per kwh (WAPDA) and pumping depths around $80 \mathrm{ft}$ (this depth 
Table 6.7 Baseline vs. Sustainable Groundwater Usage Model

\begin{tabular}{lcccc}
\hline & Baseline & Capped pumping & Difference & Percentage of baseline \\
\hline Objective value (PRs, billions) & 2544 & 2506 & 38 & 98 \\
Total production (1,000 tons) & 94,047 & 89,385 & $-4,662$ & 95 \\
Punjab & 64,983 & 61,428 & $-3,555$ & 95 \\
Sindh & 24,225 & 23,434 & -791 & 97 \\
Canal diversion (MAF) & 109.6 & 109.5 & -0.1 &.. \\
Punjab & 58.1 & 58.3 & 0.2 & 101 \\
Sindh & 43.3 & 42.8 & -0.5 & 99 \\
Groundwater pumping (MAF) & 57.9 & 50.0 & -7.9 & 86 \\
Punjab & 54.1 & 47.0 & -7.1 & 87 \\
Sindh & 3.2 & 2.6 & -0.6 & 82 \\
\hline
\end{tabular}

Note: .. = negligible, MAF = million acre-feet.

to groundwater is the deepest value anywhere in the model), the total pumping cost used in the model is PRs 800 per AF for the baseline case. The minimum groundwater required is about 4.8 MAF where farmers have little choice but to pump from the aquifer, even when the pumping costs are very high. Because groundwater is always needed to augment surface irrigation supplies, the reduction in groundwater pumping also serves as a cap on productivity and, consequently, surface water use. The total pumping in which the net recharge is zero (that is no drop in water table) is calculated in the model to be about 48.6 MAF. This may be considered as the "safe yield" and matches earlier reported numbers (for example, 51 MAF by Qureshi 2011).

Table 6.7 shows the results of restricting the model to a groundwater abstraction at the safe yield of about 50 MAF. The table shows the economic cost for sustainable groundwater usage. The objective value decreases by PRs 38 billion (US $\$ 0.47$ billion). This represents only a 2 percent reduction, which suggests that prudent policy on groundwater management may be cost-effective, depending on an assessment of resource values. Punjab will have the most impacts in terms of crop production. On the other hand, these "costs" of sustainable groundwater usage will be more equal between Punjab and Sindh when the provincial allocation constraint is relaxed. The pumping reductions are greatest in Punjab. Note that the actual depth to groundwater does not directly affect the optimization. Thus, these results may be optimistic.

\section{Climate and Investment Scenarios}

This section presents changes in these environmental parameters under different adaptation investments. Figure 6.13 shows the results of flow to the sea and fresh groundwater net recharge with and without adaptation investments. The flow to the sea does not significantly change when adaptation investments are introduced. Part of this can be explained by examining how much surface and groundwater is used (table 6.8). The CYIELD investment uses almost the same amount of surface water as the no investment scenario. Thus, the remaining flow 
Figure 6.13 Environmental Related Outcome under Different Investments

a. Flow to the sea

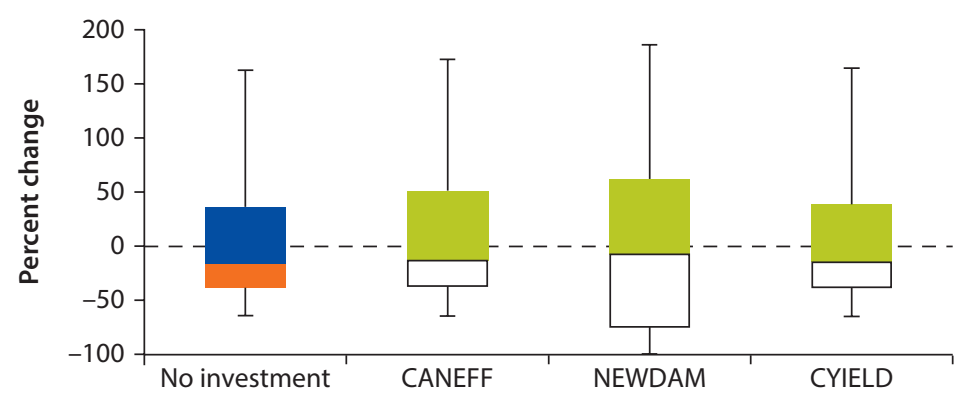

b. Fresh groundwater net recharge

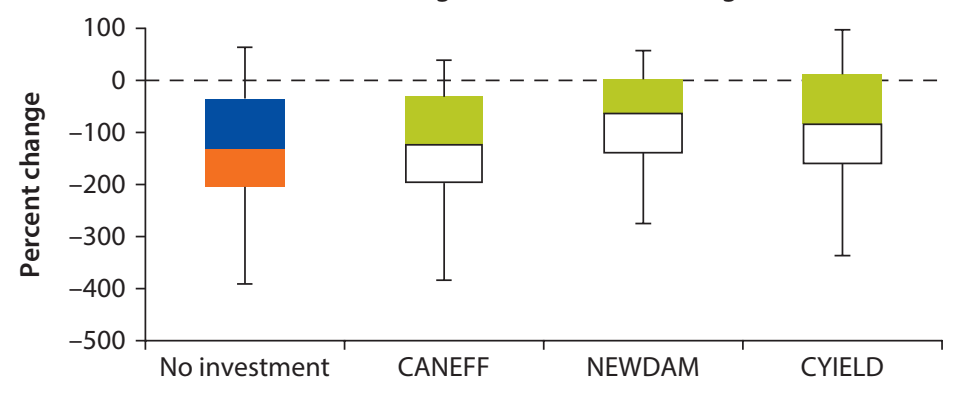

Note: $\mathrm{CANEFF}=$ canal and watercourse efficiency improvements, $C Y$ IELD $=$ crop yield, NEWDAM = construction of new reservoirs.

Table 6.8 Irrigation Mix under Different Adaptation Investments

\begin{tabular}{lccr}
\hline Average water uses under climate risk scenarios (MAF) & Canal & Tubewell & Total \\
\hline No investment & 109.8 & 66.4 & 176.2 \\
CANEFF & 108.1 & 51.6 & 159.7 \\
NEWDAM & 115.4 & 64.2 & 179.6 \\
CYIELD & 109.5 & 62.6 & 172.1 \\
\hline
\end{tabular}

Note: $\mathrm{MAF}=$ million acre-feet, $\mathrm{CANEFF}=$ canal and watercourse efficiency improvements, $C Y I E L D=$ crop yield,

NEWDAM = construction of new reservoirs.

to the sea is essentially the same. The CANEFF investment, on the other hand, diverts less surface water during the high and normal flow situations but almost the same amount during the low flow situations. This is because canal water is "free" compared to groundwater. Therefore, when CANEFF makes more surface water available, the system will divert the same amount of surface water and dramatically reduce the groundwater usage (since groundwater has a cost). Since canal diversions are almost the same, the flow to the sea value will also be the same. The range of values of flow to sea for the NEWDAM investment increases. During high flow situations, the 1991 Provincial Accord limits the amount of water that can be diverted and utilized. Thus, additional water provided by new storage cannot be used and escapes to the sea (since the model does not allow for 
the expansion of irrigated areas). During low flow situations, the additional storage will allow the system to divert more water from canal and result in less flow to the sea. This is the reason for a wider range in NEWDAM.

Similarly, the groundwater net recharge does not change significantly with these investments. Only under the NEWDAM investment is the groundwater net recharge improved. This is because more water is made available for the surface system, particularly during drought conditions. Water losses from canals and watercourses are treated as the major groundwater inflow in the model. When efficiency improves (as in the CANEFF investment), the amount of canal diversion decreases and the losses also decrease. This is a negative effect in groundwater net recharge. Moreover, pumping is reduced, which is a positive effect in groundwater net recharge (table 6.8). Thus, these two effects offset each other. With the CYIELD investment, slightly less groundwater is used and net recharge marginally improves.

Figure 6.14 shows the salt balance in both fresh and saline areas resulting from the adaptation investments. In this study, we follow the approach taken by

Figure 6.14 Salt Accumulation in Soil Layer in Fresh and Saline Areas

a. Salt balance in soil in freshwater areas

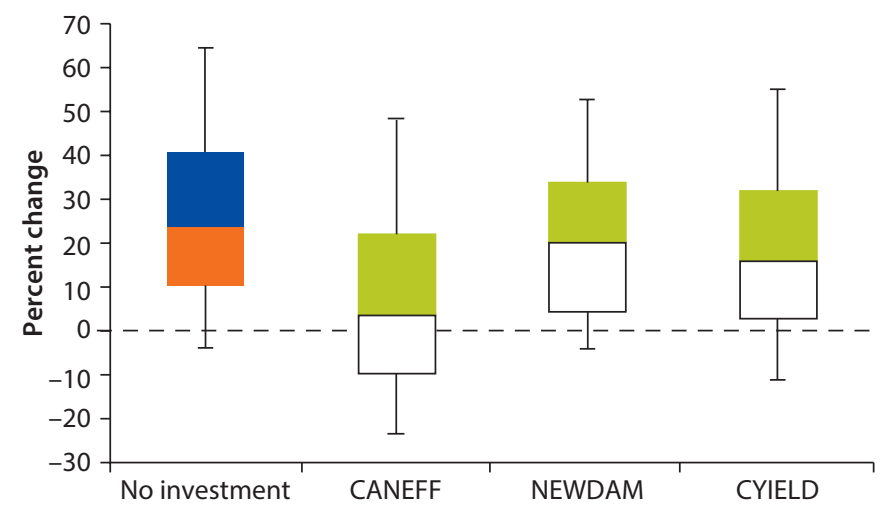

b. Salt balance in soil in saline areas

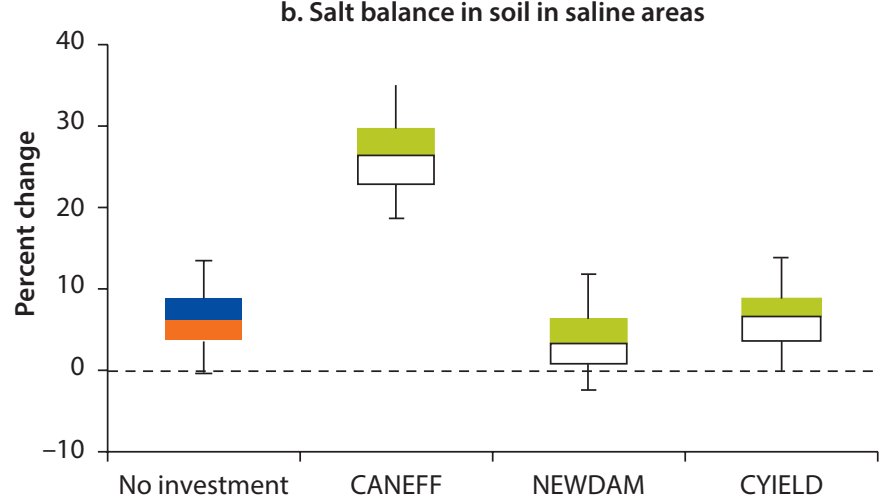

Note: CANEFF = canal and watercourse efficiency improvements, CYIELD = crop yield, NEWDAM = construction of new reservoirs. 
Ahmad and Kutcher (1992) in these calculations. For fresh areas, the largest component of salt accumulation is from pumping groundwater with background salinity. Only CANEFF, which reduces overall groundwater use, can reduce the salt accumulation in these fresh areas. With reduced fresh water flows into the saline areas (under CANEFF), the salt concentrations increase. NEWDAM and CYIELD have no significant effect on salt balance in either fresh or saline areas.

In summary, this chapter has examined the potential agro-economic impacts of some of the pressing challenges introduced in chapters 1 and 2. It has also assessed potential investment and management alternatives for the Indus Basin. This analysis was accomplished by linking an updated IBMR model with an economically broader CGE-social accounting matrix (SAM) analysis. The analysis first identified some of the key sensitivities and more robust aspects of the IBIS. At every step, key data and modeling issues, and further Indus irrigation management questions were encountered, which will be priorities for further analysis. The concluding chapter presents these main findings, their significance, and priorities for future research.

\section{References}

Ahmad, M., A. Brooke, and G. P. Kutcher. 1990. Guide to the Indus Basin Model Revised. Washington, DC: World Bank.

Ahmad, M., and G. P. Kutcher. 1992. "Irrigation Planning with Environmental Considerations: A Case Study of Pakistan's Indus Basin." World Bank Technical Paper 166, World Bank, Washington, DC.

Bastin, G. Q., S. Sarwar, and Z. A. Kazmi. 2008. "Wheat-Flour Industry in Pakistan." Discussion Paper, Competitiveness Support Fund, Islamabad.

Briscoe, J., and U. Qamar, eds. 2006. Pakistan's Water Economy: Running Dry (includes CD of background papers, 2005). Washington, DC: World Bank.

Brown, C., and J. W. Hansen. 2008. Agricultural Water Management and Climate Risk: Report to the Bill and Melinda Gates Foundation. IRI Techical report 08-01, International Research Institute for Climate and Society, Palisades, NY.

Cooley, H., J. Christian-Smith, and P. H. Gleick. 2008. More with Less: Agricultural Water Conservation and Efficiency in California-A Special Focus on the Delta." Pacific Institute, Oakland, CA.

FAO (Food and Agriculture Organization of the United Nations). 2002. World Agriculture: Towards 2015/2030 Summary Report. Rome.

Haq, N. U., and M. N. Khan. 2010. Pakistan's Water Concerns. IPRI Factfile, Islamabad Policy Research Institute, Islambad. http://ipripak.org/factfiles/ff127.pdf (accessed May 17, 2012).

Huang, J., R. Hu, C. Fan, C. E. Pray, and S. Rozelle. 2002. "Bt Cotton Benefit, Costs and Impact in China." AgBioForum 5 (4): 153-66.

Immerzeel, W. W., F. Pellicciottti, A. Gobiet, and S. Ragetti. 2011. "The Impact of Uncertainty in Climate Change Scenarios on Projection of Future Water Supply from the Asian Water Towers." Eos Trans. AGU 92 (52) Fall Meeting. Suppl., Abstract C53E-0721. 
Iqbal, M. M., M. A. Goheer, S. A. Noor, H. Sultana, K. M. Salik, and A. M. Khan. 2009. Climate Change and Wheat Production in Pakistan: Calibration, Validation and Application of CERES-Wheat Model. GCISC-RR-14, Global Change Impact Studies Centre, Islamabad.

Menrad, K., A. Gabriel, and M. Gylling. 2009. "Costs of Co-Existence and Traceability Systems in the Food Industry in Germany and Denmark." Paper presented at the Fourth International Conference on Coexistence between Genetically Modified and non-GM based Agricultural Supply Chains, Melbourne, Australia, November 10-12.

Michel, A. A. 1967. The Indus Rivers: A Study of the Effects of Partition. New Haven, CT: Yale University Press.

Naheed, G., and G. Rasul. 2010. "Projections of Crop Water Requirement in Pakistan under Global Warming." Pakistan Journal of Meteorology 7 (13): 45-51.

PRC Engineering. 1986. Technical Criteria for Rehabilitation of Canal Systems in Pakistan. Islamabad: Government of Pakistan/USAID Irrigation Systems Management Project.

Qureshi, A. S. 2011. "Water Management in the Indus Basin in Pakistan: Challenges and Opportunities." Mountain Research and Development 31 (3): 252-60.

Skogerboe, G. W., M. Aslam, M. A. Khan, K. Mahmood, S. Mahmood, and A. H. Khan. 1999. Inflow-Outflow Channel Losses and Canal Inning Cost-Effectiveness in the Fordwah Eastern Sadiqia (South) Irrigation and Drainage Project. Report R-85, International Water Management Institute, Lahore, Pakistan.

Swamee, P., G. C. Mishra, and B. Chahar. 2000. "Minimum Cost Design of Lined Canal Sections." Water Resources Management 12: 1-12.

Tariq, S. M., and S. U1 Mulk. 2005. "Sustainable, Accountable Institutions." Background paper 7 for Pakistan's Water Economy: Running Dry. Washington, DC: World Bank and Oxford University Press.

WAPDA (Water and Power Development Authority). 1990. Water Sector Investment Planning Study (WSIPS). 5 vols. Lahore, Pakistan: Government of Pakistan Water and Power Development Authority.

World Bank. 1996. Pakistan Impact Evaluation Report. Report 15863-PAK, World Bank, Washington, DC. 
